\title{
Wiley \\ Royal Geographical Society (with the Institute of British Geographers)
}

Notes on the Kunene River, Southern Angola

Author(s): F. E. Kanthack

Source: The Geographical Journal, Vol. 57, No. 5 (May, 1921), pp. 321-336

Published by: geographicalj

Stable URL: http://www.jstor.org/stable/1780840

Accessed: 21-10-2015 15:35 UTC

Your use of the JSTOR archive indicates your acceptance of the Terms \& Conditions of Use, available at http://www.jstor.org/page/ info/about/policies/terms.jsp

JSTOR is a not-for-profit service that helps scholars, researchers, and students discover, use, and build upon a wide range of content in a trusted digital archive. We use information technology and tools to increase productivity and facilitate new forms of scholarship. For more information about JSTOR, please contact support@jstor.org. 


\title{
The Geographical Journal
}

Vol. LVII No. 5

May I92I

\section{NOTES ON THE KUNENE RIVER, SOUTHERN ANGOLA}

\author{
F. E. Kanthack, C.M.G., M.I.C.E.
}

$T^{H E}$ Kunene is one of the two solitary perennial rivers draining into 1 the South Atlantic from the South African continent between Benguela (lat. $12^{\circ} 34^{\prime}$ S.) and Cape Town (lat. $34^{\circ}$ S.) ; that is, over a distance of approximately 1600 miles along the coast. The other is the Orange River I 200 miles further south, and this latter great river, which drains an area of about 336,000 square miles, is frequently reduced to a very small discharge during the spring months, and has on numerous occasions during the past century ceased to flow altogether in its lower reaches. The Kunene and Orange rivers are the northern and southern boundaries respectively of the South-West Africa Protectorate, formerly German South-West Africa. All along its 1200 miles of coast-line a great number of rivers are shown on the maps; all of them are, however, dry watercourses, discharging only at rare intervals.

The Kunene has, in recent years, attracted a considerable amount of attention due to various causes. In the first place, it has become politically important in connection with the settlement of the boundary dispute which has existed between Portugal and Germany for the past thirty-four years. Secondly, Prof. Schwarz's propaganda in favour of his theories and scheme for recreating the Kalahari lakes and swamps and thereby changing the climate of South Africa, has made many people familiar with the Kunene by name.

The Kunene is an important factor in Prof. Schwarz's projects, and it is unfortunate that he did not possess first-hand or even accurate information about it before formulating his scheme, as many of his vital data concerning this river are erroneous. Prof. Schwarz is not the only one who has gone astray owing to wrong information about this river.

During July and August of 1920 I was in charge of the British Commission which met a Portuguese Commission at the great falls of Rua Cana on the Kunene to negotiate a settlement of the old standing frontier dispute and to delimit the boundary. The British commissioners were, so far as is known, the first Britishers to explore properly the Kunene between Erickson's Drift and the great falls-the most interesting and 
important section of the river. It was from the outset apparent that nearly all the information concerning this section of the river, both official and otherwise, was erroneous and wholly misleading. The Portuguese have known this river intimately for a very long time, and the paucity of reliable information regarding so important a geographical feature is surprising.

The time appears now opportune to place on record a few facts relating to the Kunene, and more especially to the short length of about 30 miles in which it makes its first great plunge from the high Southern African tableland down the great coastal escarpment to the Atlantic Ocean.

Before dealing with the particular length of the river in question it is desirable to give some general information about the Kunene and its great sister river the Okavango, as in dealing with any of the diverse problems which may arise concerning the reclamation of the great plains of Ovamboland or the Kalahari, both these rivers must be dealt with.

The drainage areas of the Kunene and the Okavango rivers lie side by side, and the watershed separating them has no very pronounced topographical features. The headwaters of both rivers lie between the I 2 th and I $3^{\text {th }}$ degrees of south latitude, on the crest of the Angola highlands. The watershed between the Kunene and Okavango, flowing south, and the river systems draining north-west to the Atlantic or northwards to the Congo likewise presents no striking features. This watershed is followed very closely by the railway from Lobito Bay to the Katanga area.

The information given in these notes regarding the catchment areas of the two rivers is based upon the I9I 7 edition of the $1 / 2,000,000$ Portuguese map of Angola published by the Comissão de Cartografia. This edition is supposed to be entirely new, and in the levels shown there are many differences from the previous edition of I9I2. An article in vol. $3 \mathrm{I}$ of the Mitteilungen aus den Deutschen Schutzgebieten entitled "Studien über Angola" has also been made use of.

The general structure of southern Angola is but little different from that obtaining further south. Along the Atlantic coast there is a belt of arid country varying from 50 to roo miles. Then comes the great coastal barrier or escarpment, on the top of which is the vast plateau extending east for hundreds of miles with but little variation in level from west to east, but with a very gradual fall to the south from the central watershed.

From levels shown on the map it is possible to plot approximately longitudinal sections of the two rivers. The recorded levels are, however, not bed levels, but refer to spots on or near the banks, such as police or military posts. These are, in many cases, at an appreciable height above the river-bed. Allowing for this, the gradient of the Kunene bed from Kiteve to Erickson's Drift, i.e. over a distance of roo miles, is somewhere between $\mathbf{I} / 3000$ and I/4000. It is clear, however, that, speaking generally, 
the Okavango River has a much flatter gradient than the Kunene and is a much more sluggish river.

Considering the great length of time Angola has been settled, the

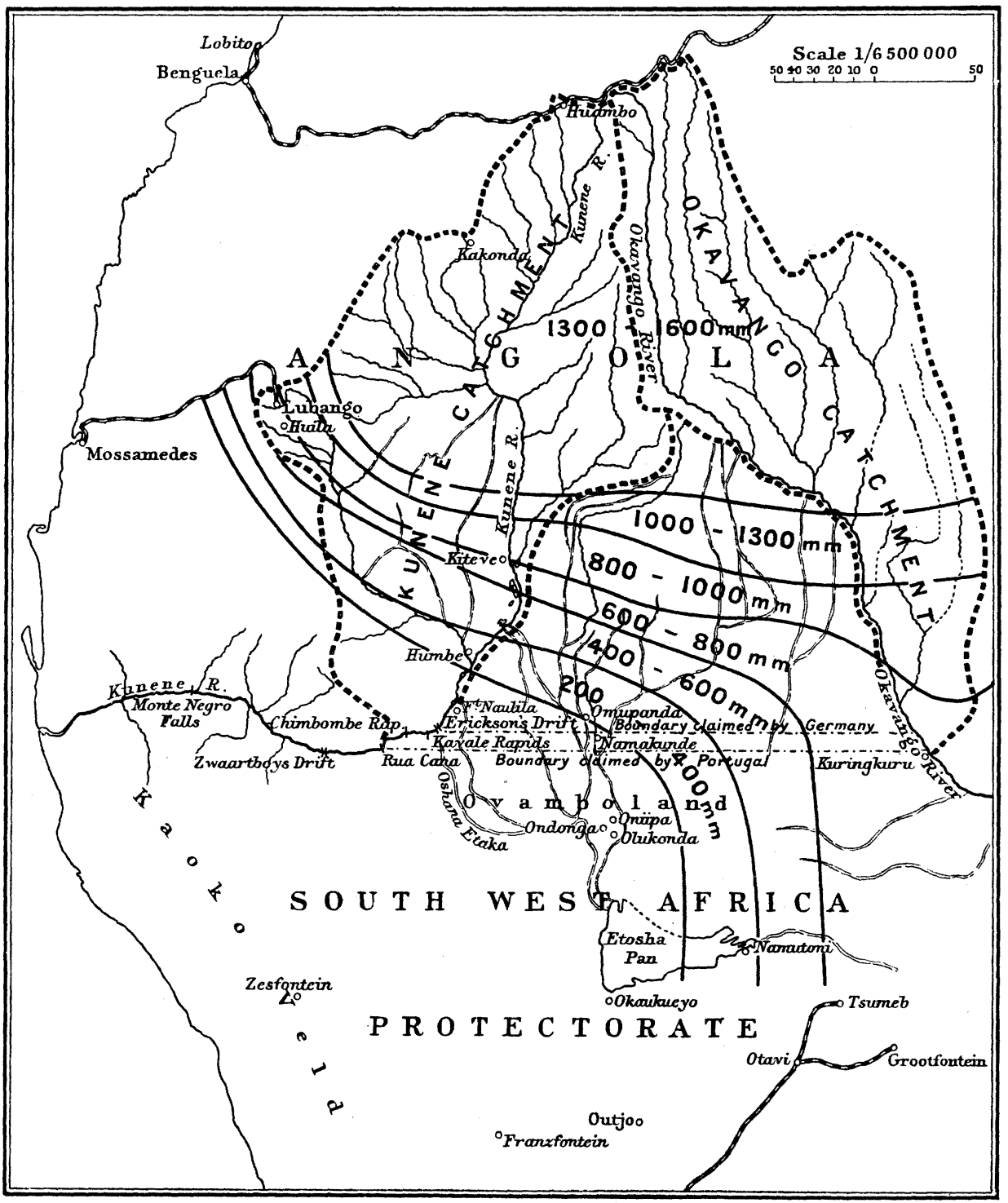

Rainfall of Kunene and Okavango Basins

paucity of meteorological data and the short period over which these extend is surprising. The accompanying table of mean annual rainfall in southern Angola and in the territory immediately to the south of it has 
been prepared by the Meteorological Department of the Union of S.A. Table No. II. shows the seasonal distribution of rainfall in the Huila district of southern Angola, which is typical of the whole area within the catchments. The only useful information on the subject of rainfall in this country is derived from German sources, and an article on the Meteorology of southern Angola in vol. 30 of the Mitteilungen a.d. Deutschen Schutzgebieten has been drawn upon. It will be seen from Table No. II. that there is a pronounced dry season varying from four to six months, between May and October, followed by a wet period. The latter has generally two peaks, one in December and the other in March. During January and February the rainfall is less. The figures in the table, which are calculated only over a very short period of time, do not indicate this as clearly as is said to be the case by reliable Portuguese officers who have been in the country for a long time. From close observation on the Kunene by these officers, it appears that there is a minor flood period in November and December, following the six months' drought, then a lull in January and February; and finally the main flood period during March and April.

For the purpose of calculating the run-off, I have divided the catchments of the two rivers into zones according to the mean rainfall in each. The particulars are given in Table III. It will be seen that the Kunene catchment above the Kavale Rapids, near Erickson's Drift, is about 30 per cent. larger than the Okavango catchment above Kuringkuru, near the border between Angcla and the South West-Africa Protectorate. The whole of the Okavango catchment above this point is in regions of good rainfall, whereas about 4000 square miles of the Kunene catchment is in arid or semi-arid country from which the run-off is either nothing or very small.

\section{TABLE I.}

Rainfall in Southern Angola and Northern S.W.A. Protectorate.

\begin{tabular}{|c|c|c|c|c|c|c|c|}
\hline Station. & & & Lat. S. & & Long. E. & & $\begin{array}{l}\text { age rainfal } \\
\text { illimetres. }\end{array}$ \\
\hline Loanda ... & ... & $\cdots$ & $8^{\circ} 49^{\prime}$ & $\cdots$ & $13^{\circ} 13^{\prime}$ & $\ldots$ & 270 \\
\hline Malange ... & $\ldots$ & $\ldots$ & $9^{\circ} 33^{\prime}$ & $\ldots$ & $16^{\circ} 3^{\prime}$ & $\ldots$ & 1240 \\
\hline Kakonda ... & $\ldots$ & ... & $13^{\circ} 44^{\prime}$ & $\ldots$ & $15^{\circ} 2^{\prime}$ & $\ldots$ & I 534 \\
\hline Villa Bandeira & ... & $\cdots$ & $14^{\circ} 49^{\prime}$ & ... & $13^{\circ} 30^{\prime}$ & ... & 978 \\
\hline Oniipa $\quad \ldots$ & $\cdots$ & $\cdots$ & $17^{\circ} 54^{\prime}$ & $\cdots$ & I $5^{\circ} 53^{\prime}$ & $\cdots$ & 420 \\
\hline Ondonga & $\ldots$ & $\ldots$ & $17^{\circ} 5^{8^{\prime}}$ & $\ldots$ & $15^{\circ} \quad 5^{\prime}$ & $\ldots$ & 412 \\
\hline Olukonda & ... & $\cdots$ & $18^{\circ} 00^{\prime}$ & $\ldots$ & $16^{\circ} 00^{\prime}$ & $\cdots$ & $53^{8}$ \\
\hline Namutoni & $\ldots$ & $\cdots$ & $18^{\circ} 48^{\prime}$ & $\ldots$ & $16^{\circ} 5^{2}$ & $\ldots$ & $3^{8} 4$ \\
\hline Okakweyo & $\cdots$ & $\cdots$ & $19^{\circ} 10^{\prime}$ & $\cdots$ & I $5^{\circ} 54^{\prime}$ & $\cdots$ & 397 \\
\hline Zesfontein & $\cdots$ & $\cdots$ & $19^{\circ} \quad 16^{\prime}$ & $\cdots$ & $13^{\circ} 37^{\prime}$ & $\cdots$ & 37 \\
\hline Grootfontein & $\cdots$ & $\cdots$ & 19032 & $\cdots$ & 18 & $\cdots$ & $5^{67}$ \\
\hline Otavi $\quad \ldots$ & $\cdots$ & $\cdots$ & $19^{\circ} 40^{\prime}$ & $\ldots$ & $17^{\circ}$ & ... & $54 \mathrm{I}$ \\
\hline Dutjo $\quad$... & $\cdots$ & $\cdots$ & $20^{\circ} \quad 6^{\prime}$ & $\ldots$ & $16^{\circ} \quad 6^{\prime}$ & $\cdots$ & 423 \\
\hline Franzfontein & $\cdots$ & $\cdots$ & $20^{\circ} 12^{\prime}$ & $\ldots$ & $15^{\circ} 00^{\prime}$ & $\ldots$ & 225 \\
\hline
\end{tabular}




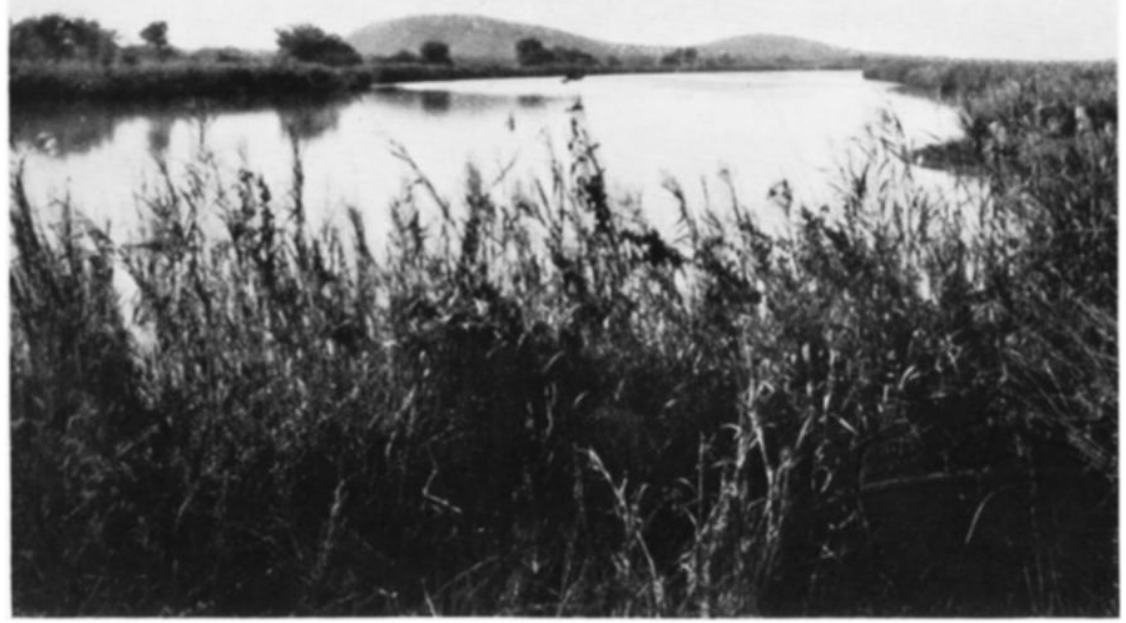

KUNENE RIVER NEAR ERICKSON'S DRIFT

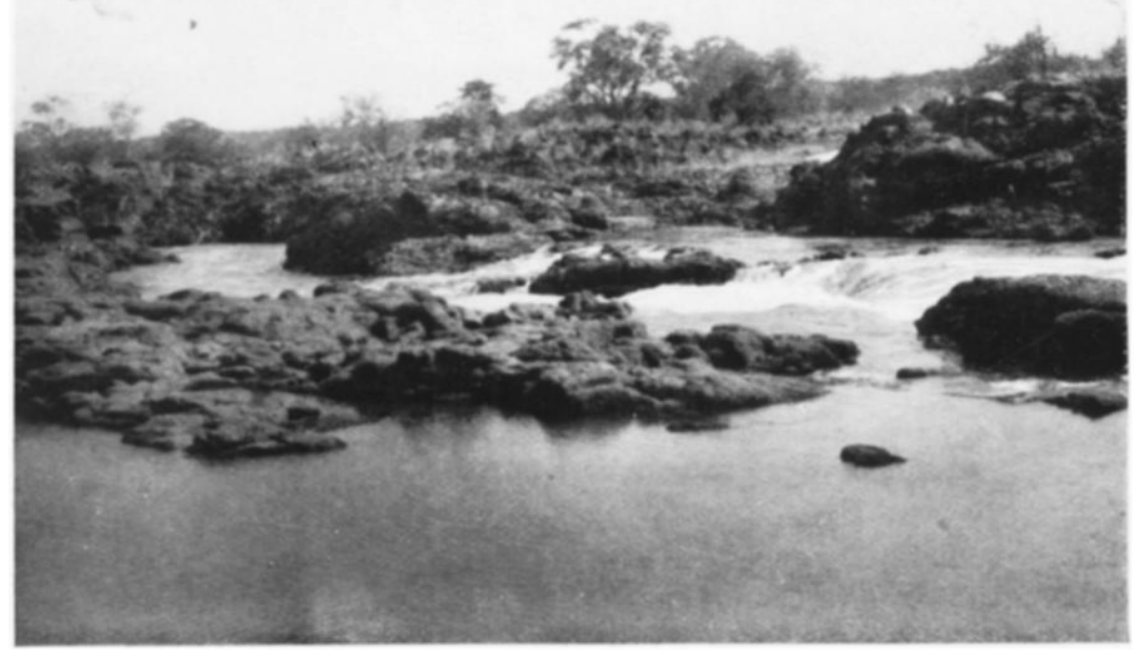

THE UPPER KAVALE RAPIDS 


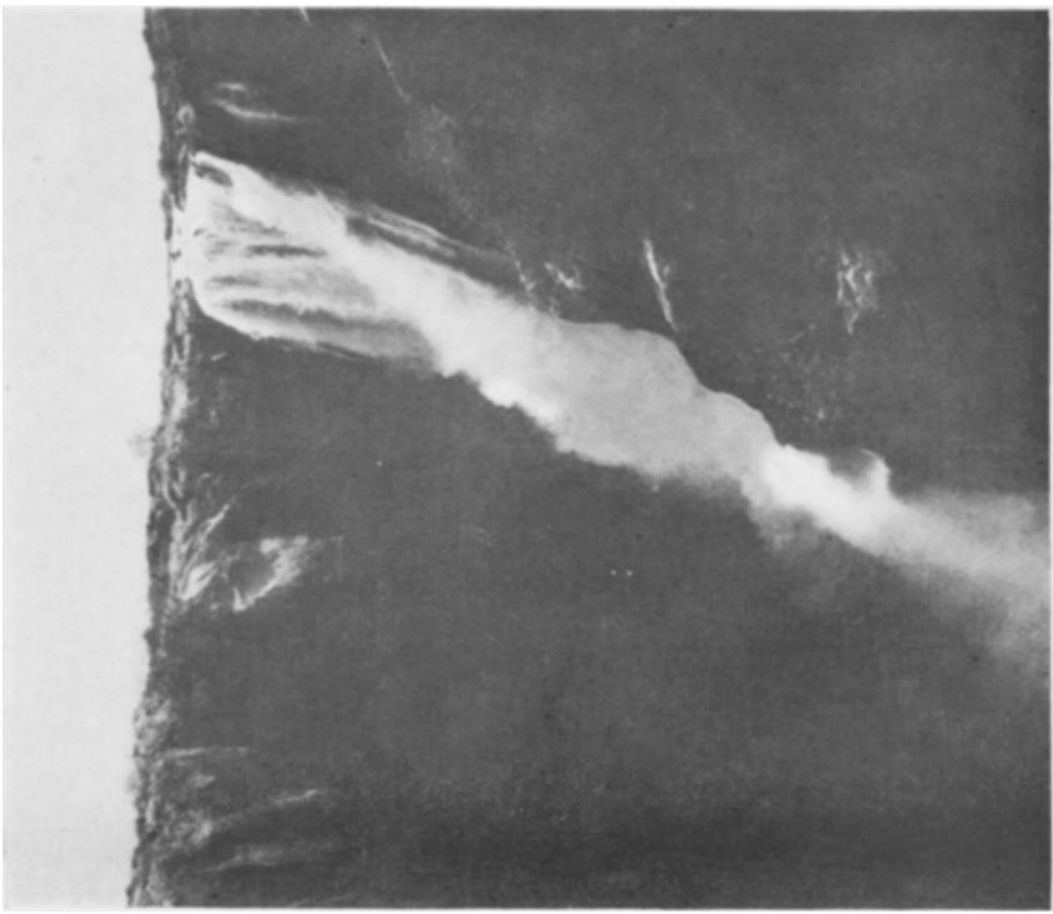

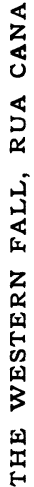

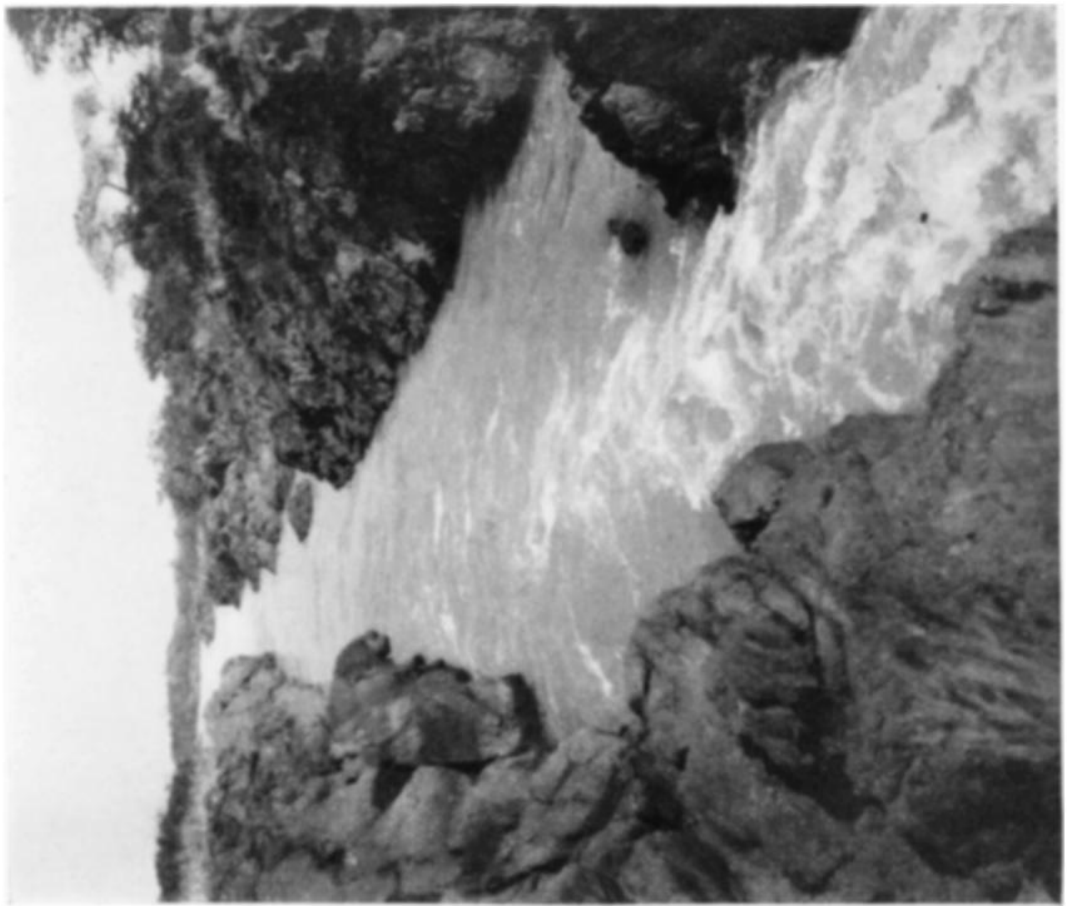


TABLE II.

Mean Monthly Rainfall in mm. in Southern Angola.

\begin{tabular}{|c|c|c|c|c|c|c|c|c|c|c|c|c|c|}
\hline Station. & Jan. & Feb. & Mar. & Apr. & May. & June. & July. & Aug. & Sept. & Oct. & Nov. & Dec. & Total. \\
\hline $\begin{array}{ll}\text { Sa. da } & \text { Bandeira } \\
\text { Huila } & \ldots \\
\text { Omupanda } . . . & \ldots \\
\text { Kakonda } & \ldots\end{array}$ & $\begin{array}{r}95 \\
\text { IOI } \\
\text { I2I } \\
245\end{array}$ & $\begin{array}{l}105 \\
161 \\
160 \\
408\end{array}$ & \begin{tabular}{|r|}
163 \\
200 \\
80 \\
280
\end{tabular} & $\left|\begin{array}{r}157 \\
67 \\
56 \\
194\end{array}\right|$ & \begin{tabular}{r|}
13 \\
4 \\
6 \\
25
\end{tabular} & $\begin{array}{l}- \\
- \\
-\end{array}$ & $\begin{array}{l}- \\
-\end{array}$ & $\begin{array}{l}\text { 二 } \\
\text { 二 }\end{array}$ & \begin{tabular}{r|r}
12 & 7 \\
11 & \\
45
\end{tabular} & $\begin{array}{r}46 \\
33 \\
5 \\
118\end{array}$ & $\begin{array}{r}138 \\
136 \\
43 \\
192\end{array}$ & $\begin{array}{l}151 \\
193 \\
141 \\
24 I\end{array}$ & $\begin{array}{r}880 \\
902 \\
624 \\
1784\end{array}$ \\
\hline
\end{tabular}

TABLE III.

KUNENE River ABove ERICKSON'S DRIFT.

Catchment areas, rainfall and estimated run-off.

\begin{tabular}{|c|c|c|c|c|c|c|}
\hline Zone. & \multicolumn{2}{|c|}{ Rainfall. } & $\begin{array}{l}\text { Area in } \\
\text { sq. miles. }\end{array}$ & $\begin{array}{l}\text { Total rainfall in } \\
\text { cub. feet per annum } \\
\text { (approx.). }\end{array}$ & $\begin{array}{l}\text { Run-off per- } \\
\text { centage } \\
\text { assumed. }\end{array}$ & $\begin{array}{l}\text { Total run-off in } \\
\text { cub. feet per annum } \\
\text { (approx.) }\end{array}$ \\
\hline $\begin{array}{l}1 \\
2 \\
3 \\
4 \\
5 \\
6 \\
7\end{array}$ & $\begin{array}{r}\mathrm{mm} . \\
\text { I } 500 \\
\text { I I } 50 \\
900 \\
700 \\
500 \\
300 \\
100\end{array}$ & $\begin{array}{c}\text { ins. } \\
59^{\circ} 02 \\
45^{\circ} 28 \\
35^{\circ} 43 \\
27^{\circ} 5^{\circ} 6 \\
19 \cdot 68 \\
11^{\circ} \cdot 81 \\
3^{\circ} 94\end{array}$ & $\begin{array}{r}21,830 \\
2,227 \\
2,079 \\
1,733 \\
2,970 \\
2,722 \\
1,336\end{array}$ & $\begin{array}{r}2993 \times 10^{9} \\
234 \times 10^{9} \\
171 \times 10^{9} \\
111 \times 10^{9} \\
136 \times 10^{9} \\
75 \times 10^{9} \\
12 \times 10^{9}\end{array}$ & $\begin{array}{r}10 \\
9 \\
8 \\
7 \\
5 \\
2 \\
1\end{array}$ & $\begin{array}{r}299^{\circ} 0 \times 10^{9} \\
21.0 \times 10^{9} \\
13.5 \times 10^{9} \\
8.0 \times 10^{9} \\
7.0 \times 10^{9} \\
1.5 \times 10^{8} \\
-\end{array}$ \\
\hline & & & 34,897 & $373^{2} \times 10^{9}$ & & $35^{\circ} 0 \times 10^{9}$ \\
\hline
\end{tabular}

TABLE IV.

\section{Okavango River above Kuringkuru.}

Catchment areas, rainfall and estimated run-off.

\begin{tabular}{|c|c|c|c|c|c|c|}
\hline Zone. & \multicolumn{2}{|c|}{ Rainfall. } & $\begin{array}{l}\text { Area in } \\
\text { sq. miles. }\end{array}$ & $\begin{array}{l}\text { Total rainfall in } \\
\text { cub. feet per annum } \\
\text { (approx.). }\end{array}$ & $\begin{array}{l}\text { Run-off per- } \\
\text { centage } \\
\text { assumed. }\end{array}$ & $\begin{array}{l}\text { Total run-off in } \\
\text { cub. feet per annum } \\
\text { (approx.). }\end{array}$ \\
\hline \multirow{5}{*}{$\begin{array}{l}1 \\
2 \\
3 \\
4\end{array}$} & \multirow{5}{*}{$\begin{array}{r}\mathrm{mm} . \\
1500 \\
1150 \\
900 \\
700\end{array}$} & \multirow{5}{*}{$\begin{array}{c}\text { ins. } \\
59^{\circ} 02 \\
45^{\circ} 28 \\
35^{\circ} 43 \\
27^{\circ} 5^{\circ}\end{array}$} & 21,206 & $2908 \times 10^{9}$ & 10 & $20.1 \times 10^{9}$ \\
\hline & & & 2,208 & $232 \times 10^{9}$ & 8 & $19 \times 10^{9}$ \\
\hline & & & 2,475 & $204 \times 10^{9}$ & 6 & $12 \times 10^{8}$ \\
\hline & & & $84 I$ & $54 \times 10^{9}$ & 5 & $3 \times 10^{9}$ \\
\hline & & & 26,730 & $3398 \times 10^{2}$ & & $325 \times 10^{9}$ \\
\hline
\end{tabular}

* Lubango.

$\dagger$ This monthly record is for one year only. 


\section{TABLE V.}

\section{Estimated Mean Monthly Discharge of the Kunene at the Kavale} RAPIDS.

\begin{tabular}{|c|c|c|c|c|c|c|c|}
\hline Month. & & & & & $\begin{array}{l}\text { an discharge } \\
\text { in cusecs. }\end{array}$ & & $\begin{array}{l}\text { approx. volume of } \\
\text { harge in cubic feet. }\end{array}$ \\
\hline October & $\ldots$ & & & $\ldots$ & 2,000 & $\ldots$ & $5 \times 10^{9}$ \\
\hline November & $\ldots$ & $\ldots$ & $\ldots$ & $\ldots$ & 5,000 & $\ldots$ & $13 \times 10^{9}$ \\
\hline December & $\ldots$ & $\ldots$ & $\ldots$ & $\ldots$ & 10,000 & $\ldots$ & $26 \times 10^{9}$ \\
\hline January & $\ldots$ & $\ldots$ & $\ldots$ & $\ldots$ & 10,000 & $\ldots$ & $26 \times 10^{9}$ \\
\hline February & $\ldots$ & $\ldots$ & $\ldots$ & $\ldots$ & 20,000 & $\ldots$ & $52 \times 10^{9}$ \\
\hline March & $\ldots$ & $\ldots$ & $\ldots$ & $\ldots$ & 40,000 & $\ldots$ & IO $3 \times 10^{9}$ \\
\hline April & $\ldots$ & $\ldots$ & $\ldots$ & $\ldots$ & 30,000 & ... & $77 \times 10^{9}$ \\
\hline May ... & $\ldots$ & $\ldots$ & $\ldots$ & $\ldots$ & I0,000 & $\ldots$ & $26 \times 10^{9}$ \\
\hline June ... & $\ldots$ & $\ldots$ & $\ldots$ & $\ldots$ & 5,000 & $\ldots$ & $13 \times 10^{9}$ \\
\hline July ... & & $\ldots$ & $\ldots$ & $\ldots$ & 2,000 & $\ldots$ & $5 \times 10^{9}$ \\
\hline August & $\ldots$ & $\ldots$ & $\ldots$ & $\ldots$ & 1,000 & $\ldots$... & $3 \times 10^{9}$ \\
\hline September & $\ldots$ & $\ldots$ & $\ldots$ & $\ldots$ & 500 & $\ldots$ & $1 \times 10^{9}$ \\
\hline & & & & & tal $\ldots$ & $\ldots$ & $350 \times 10^{9}$ \\
\hline
\end{tabular}

The total amount of rainfall running off these two catchments, measured as stream flow at Erickson's Drift on the Kunene and at Kuringkuru on the Okavango, respectively, is estimated by me to be 350,000 million cubic feet per annum in the Kunene and 325,000 million cubic feet per annum in the Okavango. For each zone I have adopted a different run-off coefficient. These coefficients have been fixed in the light of experience gained in the Union of South Africa from about fifteen years of elaborate study of stream flow in its relation to rainfall, and in my opinion these coefficients are optimistic, especially in the case of the Okavango ; though Mr. Karlson, late Hydrographic Surveyor in the Union Irrigation Department, has in a recent publication assumed as much as 20 per cent. run-off in the wettest zone of the Kunene catchment. Now while there is no very large difference in the estimated total annual run-off from the two rivers, the mode of run-off differs enormously. The seasonal variation of the Kunene flow reminds one more of the big South African rivers of the Union, having a very small discharge in the winter and spring months, and a very heavy flood discharge during the rainy season. The Okavango, on the other hand, appears to have a much smaller range, and owing to the shape and flat nature of its catchment and to its generally higher rainfall, a much higher mean discharge is maintained throughout the dry period.

The minimum flow of the Kunene has been studied with some care in recent years by the Portuguese; and during my stay on the river in July 1920 I personally watched the variations of the discharge very closely.

The possibilities of utilizing the power of the great Rua Cana falls has stimulated the Portuguese military engineers to make periodical observations of the dry-weather flow. Between 24 June and 7 July, while I was camped at various points on the banks of the Kunene, the very rapid shrinkage in the discharge was most pronounced and the daily 
fall in the water-level was appreciable. On 4 July I computed the discharge to be approximately rooo cubic feet per second, at a point a short distance above the crest of the great falls. The two Portuguese military engineers on the Boundary Commission, who had considerable knowledge of the river, informed me that at its lowest the discharge would be approximately half this amount, viz. 500 cubic feet per second. From information thus gathered, and having regard to the seasonal distribution of the rainfall, I have attempted to make an estimate of the mean monthly discharge of the Kunene below the Kavale Rapids. This is given in Table V.

From its source, for about 450 miles, the Kunene flows generally due south. It then takes a south-westerly course for the next roo miles to Erickson's Drift, after which it turns west and continues more or less in this direction to its mouth. Above Erickson's Drift it pursues a somewhat sluggish course down the great alluvial plain of southern Angola, which, in character, is practically the same as the plain of Ovamboland in the South-West Africa Protectorate. On arriving at Erickson's Drift the river has reached the western margin of the great plateau, and about 5 miles further west commences its descent down the 3000-foot escarpment to the coast.

The altitude above sea-level at the crest of the Kavale Rapids is 3215 , and the distance thence to the sea is approximately 200 miles. Erickson's Drift is the spot where the famous trader of that name is said to have taken his waggons across the Kunene into Angola. He must have been a very bold man, as it looks a most unattractive spot for such a purpose, and has not since been used. The drift is near the lower extremity of the great bend, where the Kunene changes its course to the west. The gradient is exceedingly flat, the current very small, and the margins are covered with broad belts of high reeds and swamps, which are intersected with deep creeks and pools infested with crocodiles. The great bend of the river is made round a small cluster of kopjes, composed of red sandstones and grits. These kopjes, called by the Ovashimba natives Okarundu, form a striking landmark for miles around. To the east and south of them lies the vast plain of Ovamboland. It is almost dead-flat from east to west, with a very small gradient from north to south. The plain has been formed by the fine silt brought down from the Angola highlands by the Kunene, Okavango, Chobe, and other big rivers. These deposits have in the course of ages gradually filled up the vast depression which stretched across the southern African plateau roughly between $\mathrm{r} 6^{\circ}$ and $22^{\circ} \mathrm{S}$. lat., and between $15^{\circ}$ and $27^{\circ} \mathrm{E}$. long. It is possible that at some very remote date all the drainage from the Angola highlands, then much higher, emptied itself into this great depression, but the combined processes of silting and the erosion of the coastal escarpment working eastwards, gradually diverted more and more of the waters of the Kunene catchment to the South Atlantic. In the sa me way much of the water of 
the Okavango, which at one time found its way into the Etosha Pan on the western side of the great depression, has been forced from want of gradient to seek an easier outlet south-eastwards. So far as the Kunene is concerned, it is clear from an examination of that river below Erickson's Drift that the diversion of the water to the west began at a very remote date, and that the full development of the present system occupied an immense period of time. In its present state the Kunene above Erickson's Drift has the same characteristics as other great rivers traversing alluvial plains. In normal cases such rivers gradually build up their beds to higher and higher levels till the gradient becomes too small, and when a particularly large flood overtops the banks it causes the entire river to roll off its old embanked bed and to establish a new course at lower levels in the valley. In course of time such big rivers swing slowly from side to side of their containing valleys and slowly raise the general level of the alluvial deposit. The great rivers of the Punjab and the Mississippi are typical examples of this process. In the case of the Kunene the silting-up process has reached so advanced a stage that the building-up and rolling-off process has long since been impossible. Further building up of the bed would so reduce the gradient and the velocity that the vast volume of water could no longer be transported, and a state of approximate equilibrium has now, more or less, been attained. A sufficient head of water is automatically maintained to create a large enough average velocity of flow during the flood season to keep the main channel free from silt, and enable the enormous mass of water to transport itself. During very high floods such rivers overtop their banks, and in doing so all the heavier particles of silt in suspension are deposited along the margins of the main channel, owing to the immediate reduction in velocity. The margins of these rivers are therefore invariably at. a higher level than is the alluvial land some distance away from the main channel. If the bed is free to rise the process goes on indefinitely, and the river runs on the top of an embankment, like the Indus and the Mississippi-both extreme cases. With the Kunene this, for reasons stated, is not possible, with the result that with the bed-levels stationary and the bank-levels rising, overtopping becomes more and more rare. This accounts for the steady diminution in the amount of annual flooding of the Ovamboland plains. It is necessary to insist upon the fact, however, that even were it possible to produce such overtopping on a large scale, the gradient down the plain is now so small that no really large percentage of the flow could be made to pass down southwards to the Etosha Pan. Some enthusiasts, in ignorance of the fundamental laws of hydraulics, think otherwise.

The critical point on the Kunene is the crest of the little rapid about 5 miles below Erickson's Drift. This rock barrier, fortunately a very hard one, regulates the bed-levels for many miles upstream. The great bend of the Kunene between Fort Naulila and Erickson's Drift, a distance 
of about ro miles, formed and still forms one of the main spillways to the south. Numbers of small spill channels from the south bank converge to form one of the largest of the old Oshanas, or shallow flood channels leading southwards towards the Etosha Pan. This particular channel is known as the Oshana Etaka.

A mile below Erickson's Drift the Kunene enters a clearly defined valley. The sides consist of outcrops of red felspathic grits and conglomerates which form very uniform side slopes of about I to I. Outside these outcrops the country consists, for distances up to half a mile, of hard calcareous tufa covered with very dense bush. The surface is generally level, excepting close to the banks, and rises almost imperceptibly to the sandy flats of the plains behind.

In the first 5 miles to the crest of the Kavale Rapids the alluvial floor of the valley is about ro feet below the surface of the adjoining country. For about half the distance between the drift and the rapids the river is not much broken up into channels, and for a length of about a mile is confined to a single, almost straight, channel from $\mathrm{I}_{5} 0$ to 200 yards in width. The banks of the main channel are almost vertical and from 8 to ro feet to low water. The river channels are bordered by belts of high reeds. Between the river and the southern margin of the valley there is an alluvial flat varying in width from 1000 to 2000 feet. This flat is above the ordinary flood-level. It supports patches of scrub and many scattered trees of large size, but the valley presents generally a bare appearance. On the right or Angola bank of the river conditions appear to be similar, but this side was inaccessible to us. About 3 miles below Erickson's Drift the river becomes more broken, and splits up into a number of channels, the network occupying the entire width of the valley. The ground between these channels is lower than it is further upstream, and is more exposed to flooding. A few isolated trees exist, but, in general, all the exposed land is covered with a dense growth of high reeds. Looked at from the margin of the valley, nothing but a vast expanse of reeds is visible.

Near the Kavale Rapids, about 5 miles below the drift, the valley narrows considerably, and the main stream hugs the right bank. Immediately above the rapids there is a large pool bounded on the north by high rocky banks of the valley, and on the south by a large expanse of reeds. The gradient of the river at this point is very small, and where visible presents a peaceful appearance. The Kavale Rapids are formed by a hard barrier of the same red grits and conglomerates as are referred to above, followed at lower levels by the underlying greenish biotite schists. These rapids have assumed considerable political importance, as will be shown later, and have in the past been generally referred to as the "Upper or Small Cataract" in contradistinction to the "Large Cataract," or Rua-Cana Falls, 25 miles downstream.

The Kavale Rapids are in two sections. There is first of all a rapid 
followed by a small fall, the total drop being from I $_{5}$ to 20 feet. Below the fall the main channel is in a straight narrow gorge, which is, however, of no great depth to the water surface. Below this gorge the river widens considerably, and has a fairly low gradient for a distance of approximately a mile when it reaches the crest of the second and larger fall. There are here several parallel channels. There are two large high-level channels on the left bank separated from the main channel by a long and straight high ridge, composed of schist and various igneous rocks. This ridge is covered with an almost impenetrable jungle, composed mainly of a small species of Euphorbia and masses of the very sharp Sensivera Cylindrica, together with many large trees, chiefly Mopani, and a few mighty Baobabs. The main channel below these falls has been cut deep through the red grits into the underlying schists, and the trough of the river now presents the appearance of a deeply cut gorge. The drop at these lower falls is approximately 20 feet. The total drop between the crest of the upper fall and the tail water of the lower fall is, according to levels recently taken by the Portuguese military engineers, $1 \mathrm{I} \cdot 82$ metres or $3^{8.4}$ feet. From the edge of the main valley the country, which is covered with dense forest, chiefly Mopani, and is composed of the red grits and conglomerates and calcareous tufa (derived from the former) rises some 50 to 60 feet to the sandy plateau level in 1200 yards. This series of falls and rapids, spread over a distance of a little over a mile, form the "small cataract" of the German-Portuguese boundary dispute, and should be designated by the native name Kavale Rapids or Falls.

Below Kavale the gradient of the river increases, and the valley is cut steadily deeper below the surrounding country of the plateau. Erosion near the valley margins has given the country a hilly appearance for some miles on either side, especially on the south side; and the valley is flanked by a chain of kopjes, mostly densely wooded. About a mile below the Kavale Rapids the valley is from one-half to three-quarters of a mile in width. The higher levels are throughout composed of the red grits and conglomerates, but the lower levels are now wholly composed of greenish or red schists. About 5 miles below the rapids the gradient flattens near the junction of the schists and the underlying granites. A little further down the river is confined to a single channel, which, at the time of my visit (end of July), was about roo yards wide. The bed consists of shingle, and is smooth and regular. This is the Chimbombe Drift, which forms a very easy crossing at low water. Below this drift the river is flanked on the left by the Okahe hill, the flank of which rises steeply above it. The Kunene now descends through a height of 2 I metres or 68 feet at the Chimbombe Rapids which are spread over a distance of several miles, the river throughout being split up into many channels. The river-bed is granite and other igneous rocks.

For the next 12 miles below these rapids the river maintains a westerly course, and is a succession of pools and rapids. At frequent 
intervals the valley widens, and there are extensive areas of sandy grasscovered flats which are used as cattle posts by the nomadic Ovashimba tribe of the Kaokoveld, which lies to the south. Between these spots the valley is narrow and very rough, and one is forced to proceed through the dense bush along the southern bank. About 20 miles below the crest of the Kavale Rapids the Kunene makes a sharp turn to the south, and continues in this direction till it has plunged over the great Rua Cana falls, the crest of which is approximately 24 miles below the crest of the Kavale Rapids, or 30 miles below Erickson's Drift. The total drop from the crest of the Kavale Rapids to the crest of the Rua Cana falls is I $49^{\circ} 3$ metres or 485 feet.

At the level of the crest of the great falls the plateau on the Angola side of the river consists of granites, schists, and quartzites. Approximately along latitude $I 7^{\circ} 25^{\prime} \mathrm{S}$. is the junction of these ancient rocks with the felspathic grits, sandstones, conglomerates, and tufas of the Otavi series. It is evident that the Kunene has cut its way along this junction for many miles west of the Rua Cana falls. This big drop is caused by the hard nature of the granites and schists. The valley below the falls along the junction runs due west, is straight and wide, and is flanked by high hills formed by the erosion of the great coastal escarpment. On the north bank the valley is flanked by a straight ridge, approximately 400 feet high, known as the Serra Cana range of hills. This ridge is the remains of the plateau north of the river, and is practically at the same level as the crest of the falls. The original fall must have been over the edge of this great wall. In course of ages it has cut its way back to the north, forming a zigzag gorge 400 feet deep extending to the present crest, which is just over a mile from the end of the gorge measured along the centre line. The crest of the falls is approximately 2300 feet in length, the Kunene approaching it from the north. 2000 feet above the crest the valley is about rooo feet wide, and is hemmed in by high granite slopes. The main channel, occupied by the river at low water, is in the centre and forms a straight cut through the very rough granite bed, the width varying from 50 to roo feet. About a mile further upstream the valley opens out, and in the 3 miles of its course, where it makes its big bend to the south, it is over a mile wide and very much cut up into channels, rocky islands, and reed swamps. From the narrow point, 2000 feet above the crest, the valley widens out rapidly and regularly to the crest, forming a kind of delta which is a wilderness of granite intersected by a network of channels. The right or western half of the crest runs due east and west. The left half makes an angle of $120^{\circ}$ with the western half and runs north-east to south-west. The main channel hugs the right bank of the valley, but there is an important channel running along the left margin of the delta. Below the crest lies the magnificent gorge, the walls of which are almost vertical. The main gorge starts near the centre of the falls and runs a little east of south for r 300 feet. It then 


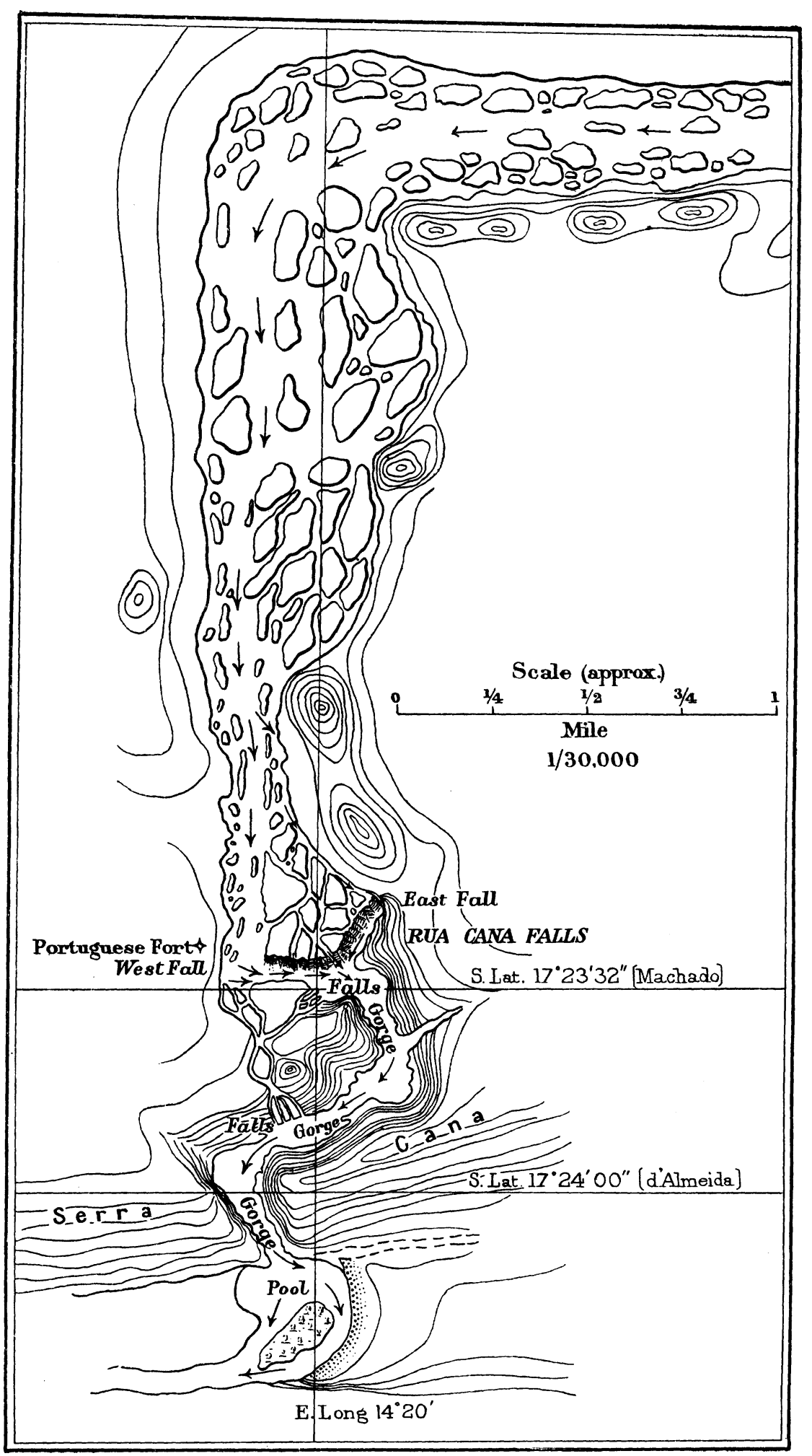

Gorges of the Kunene and Rua Cana Falls 


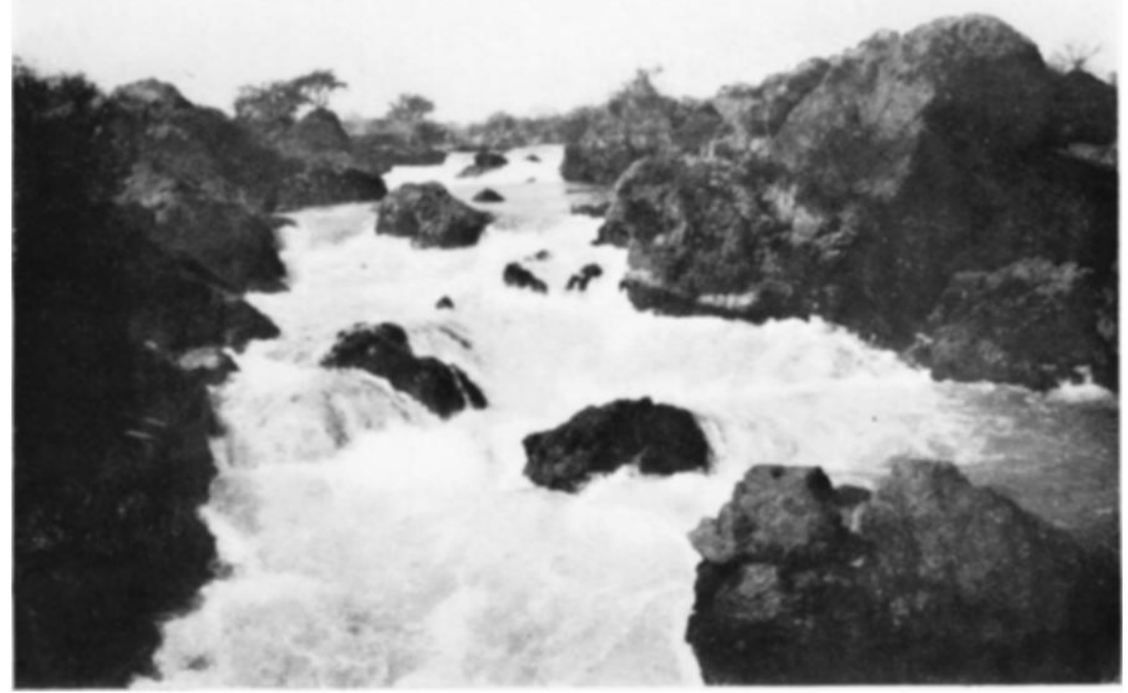

THE LOWER KAVALE RAPIDS

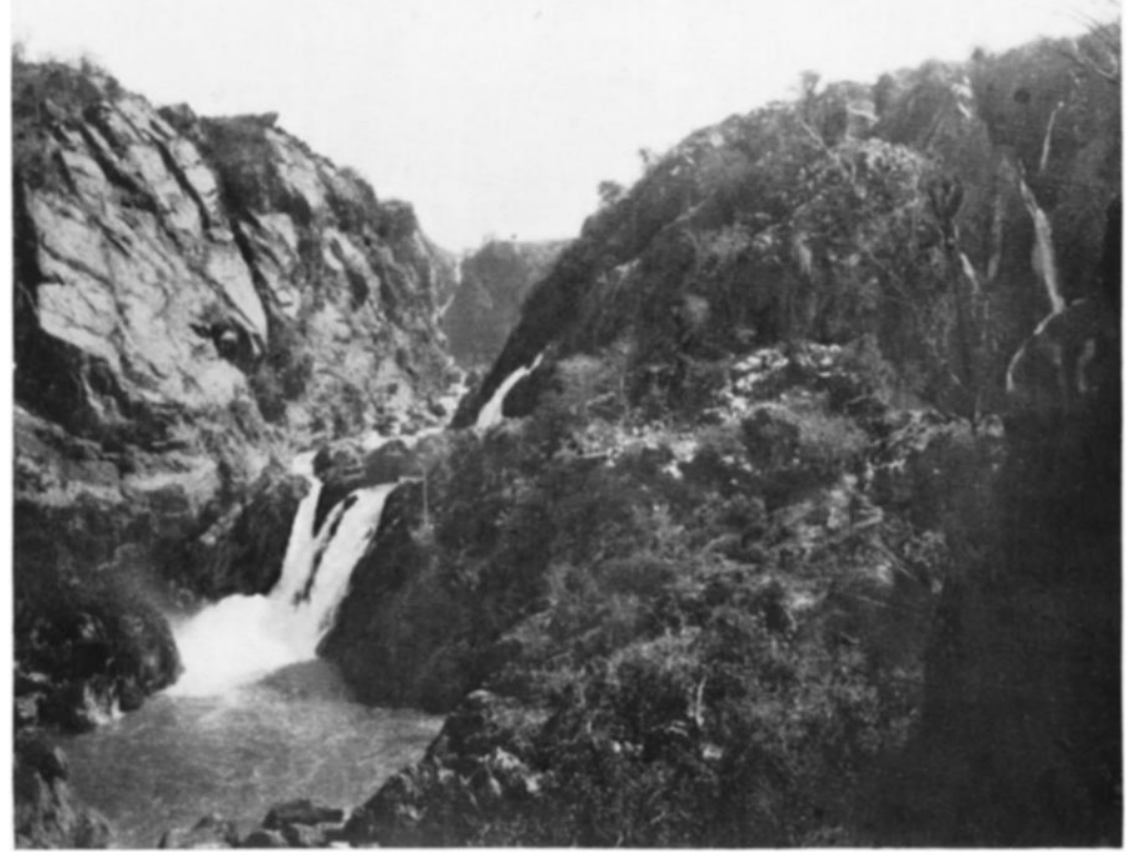

THE WESTERN GORGE, RUA CANA FALLS 


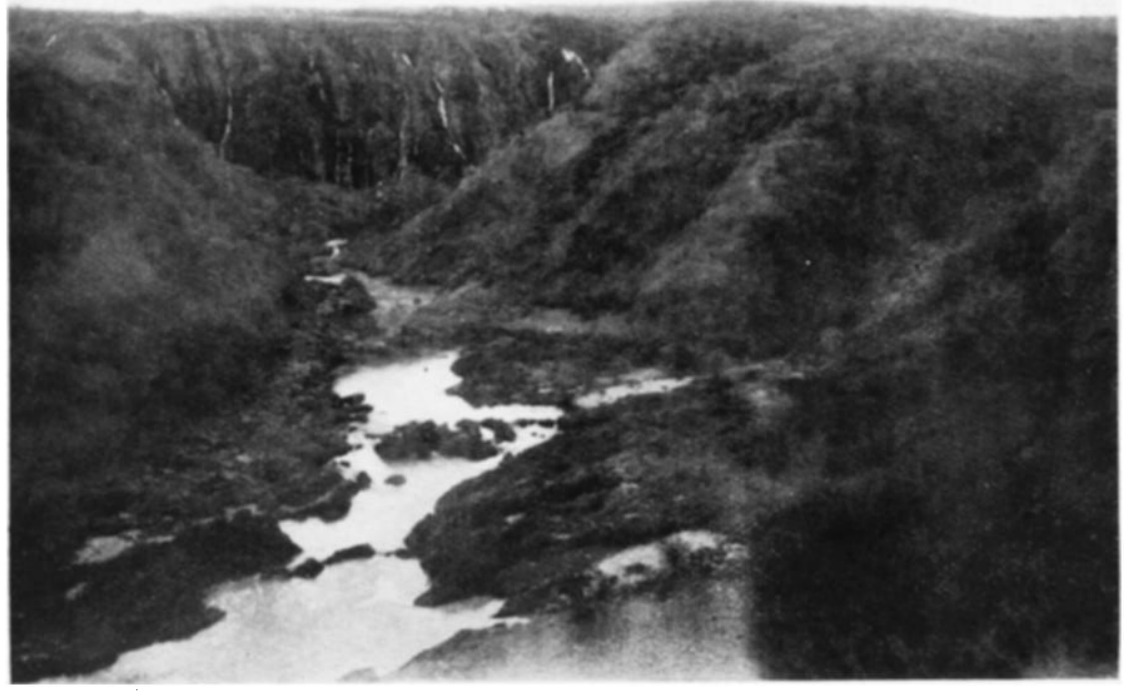

CENTRAL PORTION OF FALLS OF RUA CANA

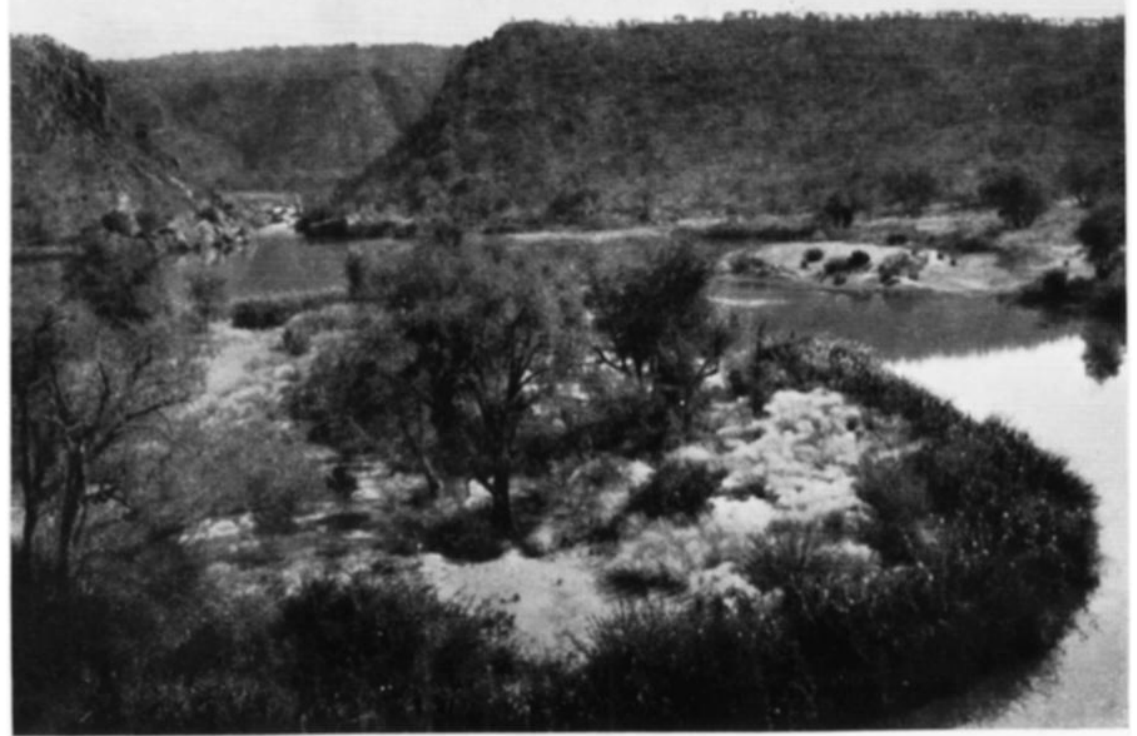

EXIT OF THE GORGE THROUGH THE SERRA CANA

This content downloaded from 129.78.139.28 on Wed, 21 Oct 2015 15:35:20 UTC All use subject to JSTOR Terms and Conditions 
turns sharp south-west, and continues in this direction for $275^{\circ}$ feet, and then finally turns through another right angle to the south-east, and in this last length of ${ }_{5} 00$ feet breaks through the Serra Cana barrier into the broad valley below, running west.

Beneath the gigantic wall under the crest of the falls the gorges run towards the centre, from the western extremity eastwards, and from northeast to south-west respectively, uniting somewhat east of the centre and discharging their combined waters into the main gorge above described. During the flood season the waterfall is continuous from one end of the crest to the other. As the discharge greatly decreases during the winter months, the fall is resolved into a large number of individual falls spread about along the face. The main discharge is, at all times, at the western extremity of the western gorge, and the next in importance is at the extreme eastern end of the fall. At extreme low water all the discharge is concentrated over these two falls, but mainly over the western one. The height of the western fall is greater than that of the eastern fall, the gorge being cut much deeper at its upper end than in the eastern gorge. The latter is much rougher, and has a very steep gradient from north-east to south-west. There are a number of minor falls over the precipices of the long north-east by south-west arm of the main gorge, which are fed by channels spilling round the western end of the main fall.

The position of the Rua Cana Falls has been fairly accurately fixed by the Portuguese military engineers and by the German surveyor Schmidt. The centre of the crest as determined by Col. Roma Machado is approximately lat. $17^{\circ} 23^{\prime} \mathrm{S}$. and long. $14^{\circ} 20^{\prime} \mathrm{E}$. The crest of the Serra Cana ridge at the point where the Kunene breaks through it was determined by d'Almeida and is on lat. $17^{\circ} 24^{\prime} \mathrm{S}$. The longitude does not appear to have been determined. The total height of the falls from the crest to the pool below the gorge is 406 feet, the altitudes being approximately as follows : crest level, 2730 ; pool level, 2324.

Below the falls the south bank of the Kunene is composed of a vertical bluff, some $5 \circ$ feet in height, of hard calcareous tufa, the valley being here 1500 feet wide. Above this bluff is a limestone terrace 2000 feet wide, which is succeeded by a high escarpment of the red felspathic grits, and above this again there is an immense plateau of hard tufa. The red grits, etc., referred to, which compose all the higher levels on the south bank, are classed as part of the Otavi beds by the German geologists, and are probably portions of the basal beds of the Nama system which lies unconformably upon the schist formation in the region of the Rua Cana Falls. The grits, etc., are of a carmine to purple colour. The fragments consist of quartz and pink felspar up to three-quarters of an inch in length. The felspar is mainly of microline, but some of orthoclase and of plagioclase is also present. The matrix is partly ferruginous and partly siliceous. There is to be seen every stage of change from the unweathered rock to calcareous tufa, with the secondary calcification of the cementing material. The 
above is based upon descriptions of hand specimens by Sidney $\mathrm{H}$. Haughton, geologist, on the staff of the S. African Museum at Cape Town.

Of the Kunene below the falls very little is known. Major Manning, Resident Commissioner of Ovamboland, reached Zwaartboys Drift in 1919 from the Kaokoveld and reported the valley as being cut deep in the mountains and very rough and wild. He was, however, unable to spend any time on the river or to make any exploration up or down-stream. At the Monte Negro Falls or Rapids, the Kunene is said to make a drop even greater than at Rua Cana, but the information about these rapids is very vague. The officers of the Portuguese Boundary Commission hoped to explore and survey them during the latter part of 1920 . The length of the Kunene described is very wild and unapproachable, and access is only possible along the south bank. The margins are covered with dense forest and are teeming with big game of every description.

Before concluding I will briefly describe the dispute and the difficulties concerning the international boundary. The boundary line between German South-West Africa and Angola was defined in an agreement between the German Imperial Government and the Kingdom of Portugal, which came into force on 30 December 1886 . In terms of this treaty the boundary was to follow the course of the Kunene river from its mouth to those waterfalls which are situated south of Humbe, at the point where the Kunene breaks through the Serra Cana. From that point the boundary was to follow the parallel of latitude through it right across to the Okavango river, and thence follow the course of that river as far as Andara, and thence again due east to the Catima Falls on the Zambesi. Whilst the definition given in the treaty is fairly clear, it had been the subject of a dispute between the German and Portuguese Governments until the occupation of German South-West Africa by the British forces in 1915. During 1916 the matter came up for consideration by the British and Portuguese Governments. The dispute has centred round the precise spot through which the parallel of latitude from the Kunene to the Okavango should be drawn. The Portuguese assumed for this purpose the high point on the Serra Cana ridge immediately above the downstream portal of the great gorge below the Rua Cana Falls (lat. $17^{\circ} 24^{\prime}$ S.). The Germans, on the other hand, made the somewhat ingenious claim that the parallel of latitude must be drawn through the uppermost of the falls below Humbe, viz. the Kavale Rapids, generally known as the "Small Cataract," some 5 miles below Etickson's Drift and 24 miles above the Rua Cana falls. The latitude of the Kavale Rapids is approximately $17^{\circ} \mathbf{I} 7^{\prime} \mathrm{S}$. The rival boundaries were thus some miles apart measured from north to south. As the disputed zone, which by the way measures about 300 miles from east to west, is, in its central regions, occupied by large and warlike tribes, the Ovakwanyamas, there has been considerable friction in the past. Since 1916 a provisional agreement has been come to between the local British and Portuguese administrations under which a belt of country 
6 miles in width, measured south of the old mission station of Namakunde, is administered, as a neutral zone, jointly by a British and Portuguese resident commissioner. This agreement was fixed up arbitrarily and somewhat regardless of even such data as were available at the time, as the latitude of Namakunde, as determined by the German surveyor Schmidt, shows that place to be $2 \mathrm{~km}$. south of the boundary line as claimed by the Germans. As the zone throughout its great length and breadth is dead flat, excepting in the length along the Kunene west of Erickson's Drift, and is, to a large extent, covered with dense forest, it is obvious that the limits of the zone are very vague, a circumstance which is a constant source of trouble, worry, and irritation to all concerned.

The settlement of the dispute formed the subject of investigation and correspondence between the British and Portuguese Governments in the years following the defeat of the German forces in I9r5, and at the end of rgrg each country appointed a commission to meet on the spot and arrive at a settlement of the dispute. The commissions were composed of the following officers :-

Representing the British Government: Francis Edgar Kanthack, C.M.G., Director of Irrigation for the Union of South Africa, Chairman; Herman Eugene Schoch, Surveyor-General, Transvaal; and Major Charles Nicolson Manning, Resident Commissioner, Ovamboland.

Representing the Portuguese Government: Colonel of Engineers Carlos Roma Machado de Faria e Maia, Commissioner; Luiz de Menezes Leal, Captain of Engineers, Captain Jose Luiz Goncalves Canelhas, Assistants.

The two commissions, after making preliminary investigations on their own account, met and commenced negotiations at the Rua Cana Falls on 30 June I920, and an agreement concerning the delimitation of the international frontier between Southern Angola and the South-West Africa Protectorate was signed at the Portuguese camp adjoining the Rua Cana falls on 6 July 1920. The agreement remains to be ratified by the British and Portuguese Governments, and until this is done no further details can be given.

\section{APPENDIX.}

The spelling of place-names demands some explanation. The spellings shown on the maps have in many cases been taken from Portuguese sources, and are often very much mutilated versions of native names. The great difficulty with the lower Kunene region lies in the fact that the country is practically uninhabited and is only visited spasmodically by the nomadic Ovashimba tribes of the Kaokoveld. A large number of these natives accompanied the Commission as porters, and the headman who brought them is an old experienced hunter with great knowledge of the country traversed. The utmost pains were taken to ascertain the recognized names of rivers, rapids, falls, hills, and the like, and these have been adopted, e.g. Kavale, Chimbombe, Okahe, Okarundu, Etaka. 
The spelling of the name Erickson is that given by the son of the old trader and hunter who travelled extensively in Ovamboland and southern Angola years ago, and whose name figures frequently on maps of these parts. The son, who is personally known to the present British Resident Commissioner for Ovamboland, informed the latter that his father claimed to be British.

The origin of the names Rua Cana and Serra Cana is not known, but is probably a Portuguese corruption of an old native name. The Ovashimba recognize the name Rua Cana, but have probably learnt it from Portuguese sources.

The description of the bluff or escarpment at the great falls as the "Serra" Cana or Cana Range is most misleading, as it is really no range of hills at all. The term was, however, used in the German-Portuguese treaty of I886 and in all subsequent official correspondence and has therefore been retained. The Germans called the country between the Angola boundary and the Etosha Pan "Amboland," but I think this term is incorrect. It is locally unknown. It is the country inhabited by the very distinct Bantu tribe of the Ovambo, and is known officially, both to the Portuguese and South African Union Governments, as "Ovamboland," and the term Amboland should no longer be used.

\title{
INTERNATIONAL AERONAUTICAL MAPS
}

\author{
Lieut.-Col. E. F. W. Lees, D.S.O.
}

Read at the Meeting of the Society, 17 Fanuary 1921. Maps following p. 400 .

$7 \mathrm{HE}$ subject of an International Aeronautical Map was first dis1 cussed some nine years ago, when, in September I9 I r, Monsieur Lallemand read before the British Association at Portsmouth a paper entitled "The International Air Map and Aeronautical Marks." His opening sentence was, "The dirigible air balloon, and more especially the aeroplane, which are to-day scarcely out of the period of research and experiment, will soon enter the area of practical politics. It is time that aviators were given means for finding their way similar to those which, for a long time, have existed for navigators and travellers." No definite progress towards the establishment of International Air Maps had, however, been made when the war broke out, and during the war the question was naturally in abeyance; various types of special maps, adapted for the uses of airmen, were published by different nations, but these maps were in no sense international.

Within a year after the armistice, in October I9I9, a convention was signed in Paris by some thirty nations and states. This convention laid down the regulations for aerial navigation, and, in an annex, recognized the need for an international series of aeronautical maps, and established certain general principles. These principles embody certain of the proposals which M. Lallemand put forward in rgir.

In this annex it is laid down that there shall be two series of international air maps: one series, to be known as General Aeronautical Maps, is to be on Mercator's Projection, on a scale of $3 \mathrm{~cm}$. to I degree 